\title{
Література
}

1. Божович Е. Д. Учителю о языковой компетенции школьника: психологопедагогические аспекты языкового образования / Е. Д. Божович. - М. : Изд-во Московского психолого-социального ин-та; - Воронеж: Изд-во НПО «МОДЭК», 2002. - 288 с.

2. Грітченко А. Г. Компетентність як інтеграційна характеристика вчителя трудового навчання / А. Г. Грітченко // Сучасні інформаційні технології та інноваційні методики навчання в підготовці фахівців: методологія, теорія, досвід, проблеми: [зб. наук. пр.]. - Випуск 26 / Редкол.: I. А. Зазюн та ін. - Київ - Вінниця: ТОВ фірма «Планер», 2010. - С. 218-223.

3. Дружилов С.А. Профессиональная компетентность и профессионализм педагога: психологический подход / С. А. Дружилов // Сибирь. Философия. Образование: [научнопублицистический альманах]. - Новокузнецк, 2005. - Вып. 8. - С. 26-44.

4. Зазюн I. Три кити нової філософії освіти: гуманізація, індивідуалізація, інтеграція // Директор школи, ліцею, гімназії. - 2000. - №1. - С.74-79.

5. Зимняя И. А. Общая культура и социально-профессиональная компетентность человека / И. А. Зимняя // Интернет-журнал «Эйдос». - 2006. - 4 мая. - Режим доступа к журналу: http://www.eidos.ru/journal/2006/0504.htm.

6. Карпова Л. Г. Сутність професійної компетенції вчителя // Проблеми підготовки студентської молоді до навчально-пізнавальної діяльності : [зб. наук. пр.] // Проблеми сучасного мистецтва і культури. - К.: Науковий світ, 2002. - С. 75-79.

7. Кузьмина Н. В. Акмеологическая теория повышения качества подготовки специалистов образования / Н. В. Кузьмина. - М. : Исследовательский центр проблем качества подготовки специалистов, 2001. - $144 \mathrm{c}$.

8. Маркова А. К. Психология профессионализма / А. К. Маркова. - М. : Просвещение, 1996. - C. 34-35.

9. Общая и профессиональная педагогика : [учеб. пособ. для студ., обучающихся по специальности «Профессиональное обучение»] : в 2-х книгах / под ред. В. Д. Симоненко, М. В. Ретивых. - Брянск: Изд-во Брянск. гос. университета, 2003. - Кн. 1. - 174 с.

10. Овод Ю. Професійна компетентність соціального педагога в контексті використання засобів дистанційного навчання / Юлія Овод // Вісник Львівського університету. Серія: Педагогіка. - 2009. - Ч.2. - С. 101-110.

11. Ткачук I. С. Інноваційні педагогічні технології як аспект підготовки майбутніх учителів технологічної освіти до формування в учнів технологічної культури / I. М. Ткачук // Наукові записки Тернопільського нац. пед. ун-ту ім. В. Гнатюка. Серія : Педагогіка. - Тернопіль, 2011. - № 3. - С. 278-286.

12. Хуторской А.В. Ключевые компетенцыи и образовательные стандарты [Електронний ресурс] / А. В. Хуторской // Интернет-журнал «Эйдос». - 2002. - 23 апреля. - Режим доступа к журналу: http://www.eidos.ru/news/compet.html.

Стаття надійшла до редакції 12.05.2012 p.

УДК 37.016:62

М. М. Коньок,

aсnірант,

Чернігівський нащіональний педагогічний університет

імені Т. Г. Шевченка

\section{МЕТОДОЛОГІЧНІ ВИМОГИ ДО ЗДІЙСНЕННЯ МІЖПРЕДМЕТНИХ ЗВ'ЯЗКІВ У ПРОЦЕСІ ПІДГОТОВКИ МАЙБУТНЬОГО ВЧИТЕЛЯ ТЕХНОЛОГІЙ}

Коньок М. М. Методологічні вимоги до здійснення міжпредметних зв'язків у прочесі підготовки майбутнього вчителя технологій.

У статті зроблено спробу розв'язання окремого аспекту проблеми посилення міжпредметних зв'язків на заняттях з фахових дисциплін у проиесі підготовки майбутніх учителів технологій.

Ключові слова: інтеграчія, міжпредметні зв'язки, технічні дисципліни, навчальний процес. 
Конёк Н. Н. Методологические требования к осуществлению межпредметных связей при подготовке будущего учителя технологий.

В статье сделана попытка решения отдельного аспекта проблемы усиления межспедметных связей на занятиях по профессиональным дисииплинам при подготовке будущих учителей технологий.

Ключевые слова: интеграция, межпредметные связи, технические дисииплины, учебный прочесс.

Konok M. Methodological requirements to realization of intersubject connections at future technologies teacher preparation.

In article made an attempt to the problem's separate aspect of intersubject connections strengthening decision on employments of professional disciplines at future technologies teachers preparation.

Key words: integration, intersubject connections, technical disciplines, educational process.

Актуальність проблеми дослідження. Розв'язання майбутніми спеціалістами складних виробничих і технічних завдань вимагає глибокої фахової підготовки, що зумовлює необхідність удосконалення всього навчального процесу вищого навчального закладу. Зазначеному аспекту приділено значну увагу в низці нормативних документів у галузі освіти та працях багатьох науковців-педагогів. Разом з цим, у фаховій підготовці існує низка проблем, однією з яких є посилення реалізації міжпредметних зв'язків.

Міжпредметні зв'язки дозволяють будувати пізнавальну діяльність студентів на основі загальнонаукових ідей i методів. Вони формують загальні здібності вчитися і розкривають загальні принципи побудови науки.

Аналіз останніх досліджень. Проблемі міжпредметних зв'язків у процесі підготовки учителів технологій у навчальній діяльності присвячено роботи Б. Ссипова, А. Кондратюка, В. Максимова, Л. Никольського, Н. Розенберга, Н. Сорокина, В. Стешенко.

Мета статті - визначити ефективні шляхи підвищення фахової підготовки майбутніх учителів технологій шляхом посилення міжпредметних зв'язків.

Виклад основного матеріалу. Підгрунтям міжпредметних зв'язків $\epsilon$ взаємозв'язок загального, політехнічного і професійного утворення. Ця єдність досягається шляхом посилення міжпредметних зв'язків у дисциплінах природничо-математичного циклу, формування політехнічних знань на основі загальнонаукових, зв'язку навчання 3 продуктивною працею. Провідним напрямком здійснення міжпредметних зв'язків $є$ філософський синтез знань. Питання впливу міжпредметних зв'язків на світогляд особистості досліджується педагогами Румунії, Угорщини, Польщі, Болгарії, Чехії. Польські науковці порушують, наприклад, питання про розрив між традиційним викладом основ науки і сучасним темпом ії розвитку. Вони обстоюють міждисциплінарний характер навчання, підкреслюючи роль філософії й історії науки у вищій інтеграції програм. В.Шевчук розглядає світогляд як результат планової інтеграції знань. На його думку, надія на те, що інтеграція відбудеться в розумі студента сама по собі, $є$ помилковою з дидактичної і з виховної позицій.

Підкреслюється значення зв'язків між предметами в досягненні мети загальної освіти і розглядаються, як один з актуальних принципів конструювання дидактичної системи, як умова ефективного здійснення навчання і виховання. Отже, у педагогіці помітні тенденції різнобічного вивчення ролі міжпредметних зв'язків у навчанні, що підтверджує комплексність цієї проблеми [5]. 
Аналіз розвитку ідеї міжпредметних зв'язків у педагогіці нашої й інших країн дозволяє виокремити зумовлені методологією вихідні вимоги до їх здійснення:

1) міжпредметні зв'язки повинні бути спрямовані на досягнення всебічного розвитку особистості студента в умовах стійкої системи предметного навчання і сприяти посиленню взаємозв'язку формування, розвитку і виховання;

2) міжпредметні зв'язки необхідно реалізувати в навчанні у всіх типах навчальних закладів і на всіх рівнях навчання відповідно до принципів науковості, систематичності навчання та його зв'язку з працею;

3) необхідна координація навчальних програм на основі інтеграції, комплексування предметних знань відповідно до провідних загальнонаукових ідей $[1 ; 2]$.

Пошук форм і методів інтеграції навчальних предметів 3 прагматичною метою - один з визначальних напрямків досліджень дидактів. У «Міжнародному центрі педагогічних досліджень» у м. Севру (Франція) створено спеціальну дослідницьку групу з розвитку міждисциплінарних зв'язків. Розв'язання нею питання зводиться, як правило, до побудови інтегрованих курсів («Соціальноекономічні науки», «Гуманітарні науки»), що включають «надійні» знання, потрібні студенту, щоб усвідомлено здійснювати свої права й обов'язки людини і громадянина. Інститут педагогіки природознавства (Франція) розробляє інтегрований курс, побудований з окремих міждисциплінарних «блоків»: («Рух організмів і машин», «Плавлення в природі і техніці» тощо), послідовність яких визначається викладачем. У зв'язку 3 випадковим набором комплексних тем і добором навчального матеріалу самим учителем інтеграція нерідко здійснюється без спадкоємних зв'язків 3 раніше вивченими предметами, грунтується на другорядних поняттях, навчальний матеріал групується навколо прикладних проблем. При цьому, як правило, ігноруються філософські й світоглядні питання. Інтеграція знань 3 позицій прагматизму приводить до зниження науковості й систематичності навчання [3].

Прагматичному підходу протистоїть когнітивний напрямок, що висуває в навчанні задачу розвитку інтелектуальних сил дитини. Цей напрямок виражений у теорії Дж. Брунера, який висловлюється проти методу «центральної теми» i «методу проектів» в об'єднанні різнопредметних знань. Він захищає ідею спіралевидної програми. У ній утвориться ієрархія понять одного і суміжних предметів на основі «ведучих структур», навколо яких необхідно сконцентрувати навчальний матеріал, $\mathrm{i}$ які можуть замінити засвоєння основ наук у їхньому різноманітті.

Міжпредметні зв'язки служать джерелом конструювання змісту утворення 3 окремих навчальних предметів. Загальні структурні елементи навчальних предметів створюють об'єктивні основи комплексного здійснення міжпредметних зв'язків у навчанні:

1) наукові об'єкти вивчення, факти;

2) поняття, закони, теорії; 
3) світоглядні ідеї;

4) історичні проблеми і шляхи науки;

5) методологічні основи і методи науки;

6) узагальнені способи пізнання;

7) специфічні уміння і навички;

8) мова науки;

9) виховні аспекти знань [3; 4].

До цих виокремлених раніше елементів навчального предмета необхідно додати політехнічні й прикладні знання, значно посилені в нових програмах і підручниках.

Сучасна дидактика виходить із принципу цілісного відображення науки в змісті навчання: як системи знань, як діяльності, у єдності теорії і методу, як системи ії взаємозв'язків з іншими формами суспільної свідомості і практики.

Наука - це і результат пізнання, і діяльність щодо засвоєння нових знань, навчальний предмет - це єдність знань, методів і взаємозв'язків, що формуються у студентів у процесі вивчення визначеної науки, галузі людської діяльності. Розгляд навчального предмета на абстрактному рівні у формі узагальненої моделі знань, ніби «вийнятим», ізольованим від діяльності і процесу навчання, дозволяе вичленувати в ньому сукупність знань: про об'єкт, способи діяльності, про цінності.

Розглянувши теоретичні основи реалізації міжпредметних зв'язків у професійному навчанні в межах вищих навчальних закладів, можемо зробити такі висновки:

- механізм міжпредметних зв'язків є одним із важливих складників навчального плану як документа, що визначає рівень кваліфікації випускника вищого навчального закладу;

- міжпредметні зв'язки за систематичного і цілеспрямованого впровадження сприяють удосконаленню всього процесу професійної підготовки майбутніх учителів технологій, тобто $є$ сучасним дидактичним принципом;

- основними функціями міжпредметних зв'язків $\epsilon$ освітня, розвивальна, виховна та координаційна.

Проаналізувавши досвід та практику застосування міжпредметних зв'язків на заняттях 3 фахових дисциплін, робимо висновок про те, що основними шляхами посилення реалізації цього принципу є:

- необхідність удосконалення організаційної і координаційної роботи щодо налагодження зв'язків між навчальними предметами та циклами (професійно-технічного та загальноосвітнього);

- систематичний підхід під час застосування зв'язків на теоретичних та практичних заняттях із використанням активних методів навчання;

- розроблення методичних рекомендацій, інструкцій, завдань, які орієнтують студентів на використання міжпредметних зв'язків; 
- удосконалення методики викладання, підвищення мотивації педагогічної діяльності викладачів та усвідомлення ними мети та завдань 3 посилення зв'язків між дисциплінами.

Отже, міжпредметні зв'язки - це особливо значимий у сучасних умовах наукової інтеграції чинник формування змісту i структури навчального предмета, а сама структура навчального предмета служить одним з об'єктивних джерел різноманіття їх видів і функцій.

У традиційному розподілі наук на гуманітарні, природні, технічні відбито об'єктно-предметні взаємозв'язки між ними. Такий поділ закріплено у циклах навчальних предметів, що згруповані за спільностю об'єктів вивчення суспільство, природа, праця. При цьому виникають внутрішньоциклові i міжциклові зв'язки, що систематизують знання й уміння студентів навколо загальних об'єктів пізнання.

У розв'язанні питання про морфологічну структуру навчальної діяльності як дидактичній основі міжпредметних зв'язків важливо спиратися на положення про єдність свідомості і діяльності й відповідності способів дій змісту знань студентів. Багатство змісту навчального предмета, його складна структура зумовлюють і багатогранність навчальної діяльності. Базисні компоненти навчальної діяльності, як показує аналіз, визначаються пізнавальним, практичним i ціннісно-орієнтаційним іiі характером, пов'язаним із засвоєнням відповідних видів знань, представлених в інформаційній структурі навчального предмета [7].

Пізнавальна діяльність спрямована на перетворення образів (понять, теорій, законів) об'єктів реального світу, що раніше склалися у свідомості студента, що досягається в процесі засвоєння нових знань і способів їхнього одержання. Оперування знаннями при цьому відбувається на внутрішньому рівні, і пізнавальна діяльність студента носить теоретичний характер. Міжпредметні зв'язки по лінії пізнавальної діяльності передбачені в розв'язанні на заняттях з різних фахових предметів однотипних пізнавальних задач, спрямованих на засвоєння аналогічних за своєю структурою знань (теорій, законів, понять тощо). Пізнавальні уміння, що здобуваються студентами, під впливом міжпредметних зв'язків стають узагальненими, загальнопредметними і міжпредметними.

Практична діяльність студентів - це вивчення і перетворення реальних об'єктів шляхом застосування наукових знань задля одержання нових фактів, емпіричних чи висновків опредметнених продуктів діяльності. Практична діяльність студентів реалізується в конкретних формах: трудова, фізична, експериментальна, обчислювальна, розрахунково-вимірювальна, конструктивнотехнічна, образотворча, мовна. Здійснюючи практичну діяльність, студенти засвоюють правила дій, алгоритми операцій і відповідні уміння і навички.

«Ціннісно-орієнтаційна» - це оцінна діяльність студентів. Вона відбувається в процесі засвоєння ціннісних аспектів знань, світоглядних ідей, зв’язків між наукою й ідеологією, що служать орієнтирами в навчальній діяльності студентів у процесі засвоєння всіх навчальних предметів. 
Навчальна діяльність також має специфічні прийоми навчальної роботи, формує вміння самостійної роботи 3 книгою, необхідні для самоосвіти, а також створює джерела міжпредметних зв'язків по лінії загальнонавчальних умінь - організаційно-пізнавальних, бібліографічних та інших [5; 6].

Міжпредметні зв'язки за видами діяльності студентів висвітлено в низці досліджень. Їх аналіз дозволяє стверджувати, що в основі виокремлення видів діяльності як основ міжпредметних зв'язків лежать загальні для споріднених наук методи (спостереження, експеримент) i специфічні для окремих предметних галузей способи дій, що під впливом переносу на суміжні дисципліни трансформуються в узагальнені вміння учнів.

Морфологічний поділ умінь за змістом знань і відповідними їм видами діяльності (пізнавальні, практичні, оцінні, навчальні) перетинається 3 їх функціональним поділом на репродуктивні, пошукові, творчі й міжпредметні, що виражають різний рівень сформованості вмінь студентів у процесі навчально-пізнавальної діяльності.

Висновки та перспективи подальших досліджень. Дослідження в галузі формування вмінь студентів на основі міжпредметних зв'язків виявили взаємодію загальних, особливих і одиничних компонентів дій в умінні різного рівня узагальненості. Міжпредметність умінь (і знань) - це їх функціональна якість, що здобувається в процесі переносу й узагальнення способів дій з різних навчальних предметів. Міжпредметність як якість знань і умінь відбиває їхній генезис, походження в процесі наукової інтеграції, породження нових знань і методів на перетині різних наук. Міжпредметні уміння - це здатність студента встановлювати і засвоювати зв'язки в процесі переносу й узагальнення знань і вмінь із суміжних предметів. Отже, навчальний предмет i навчальна діяльність $\epsilon$ дидактичними основами визначення міжпредметних зв'язків саме тому, що вони як системні об'єкти процесу навчання становлять єдність загального й особливого. Спільність структурних компонентів навчальних предметів і навчальної діяльності служить джерелом міжпредметних зв'язків у процесі навчання. Порівняння основних видів знань у структурі навчального предмета й у структурі навчальної діяльності учнів виявляє їхню визначену аналогію. Тому міжпредметні зв'язки в навчанні можуть здійснюватися в таких основних напрямках:

1) формування необхідних для становлення світогляду студента систем понять $з$ опорою на наукові факти, теорії, закони, ідеї, загальні для суміжних наукових галузей;

2) формування загальних для суміжних предметів умінь, і в першу чергу елементарних, на яких грунтуються більш складні методи засвоєння ідейних зв'язків між предметами;

3) формування на основі узагальнених знань і вмінь правильного оцінного ставлення до предметних знань, у чому особливого значення набувають міжциклові зв'язки і світоглядні навчальні проблеми. 


\section{Література}

1. Еремкин А. И. Система межпредметных связей в высшей школе: [аспект подготовки учителя] / А. И. Еремкин. - Харьков : Высшая школа, изд-во Харьк. гос. ун-та, 1984. -154 c.

2. Кондратюк А. П. Межпредметные связи как проблема комплексного подхода к обучению в педвузе / А. П. Кондратюк // Высшее и среднее педагогическое образование. К. : Высшая школа, 1980. - С. 3-11.

3. Максимова В. Н. Межпредметные связи в процессе обучения / В. Н. Максимова. М. : Просвещение, 1988. - 192 с.

4. Никольский Л. Н. Межпредметные связи на базе блок-схем / Л. Н. Никольский // Весник высшей школы. - 1982. - Вып. 6. - С. 26-28.

5. Розенберг Н. М. Межпредметные связи в средних профтехучилищах / H. М. Розенберг // Межпредметные связи в учебно-познавательной работе среднего профтехучилища. - К. : Высшая школа, 1976. - С. 25-42.

6. Сорокин Н. А. Межпредметные связи в профессиональной подготовке учителя / Н. А. Сорокин // Советская педагогика. - 1983. - № 9. - С. 73-78.

7. Стешенко В. В. Теоретические основы реализации межпредметных связей в учебном процессе / В. В. Стешенко. - Славянск : Изд-во СГПИ, 1995. - 118 с.

Стаття надійшла до редакції 14.05.2012 p.

УДК: 373.5: 371

Н. В. Симонович, acnipaнm,

Рівненський державний гуманітарний університет

\section{ТЕОРЕТИЧНІ ОСНОВИ ІНДИВІДУАЛІЗАЦІЇ ТРУДОВОГО НАВЧАННЯ}

Симонович Н. В. Теоретичні основи індивідуалізачії трудового навчання.

У статті розглянуто сутність індивідуалізації навчання та розкрито теоретичні основи використання індивідуального підходу в трудовому навчанні.

Ключові слова: особистість, індивідуальність, індивідуалізачія навчання, індивідуальний підхід.

Симонович Н. В. Теоретические основы индивидуализации трудового обучения.

В статье рассмотрена суть индивидуализачии обучения и раскрыты теоретические основаны использования индивидуального подхода в трудовом обучении.

Ключевые слова: личность, индивидуальность, индивидуализачия обучения, индивидуальный подход.

Simonovych N. Theoretical bases of individualization of labour training.

In the article essence of individualization of teaching is considered and theoretical bases of the use of individual approach are exposed in the labour training.

Key word: personality, individuality, individualization of teaching, individual approach.

Постановка проблеми. Аналіз соціально-педагогічної ситуації на кінець XX ст. та перспектив її розвитку на початок XXI ст., відображених у Державній національній програмі «Освіта. Україна XXI століття» та Концепції загальної середньої освіти, дозволяє зробити висновок про те, що епоха «великої дидактики», що розпочалася у XVII ст. (Я.А. Коменський), не завершується і в XXI ст.

Особистісно зорієнтована модель навчання, сутнісними ознаками якої $\epsilon$ спрямованість навчально-виховного процесу на взаємодію і плідний розвиток особистості педагога та його учнів на основі рівності у спілкуванні 